\title{
A European or a National Solution to the Democratic Deficit?
}

\author{
Alain Brun
}

I agree with Rainer Bauböck on his starting point. It is indeed contrary to EU law if EU citizens who take up residence in another member State lose fundamental rights as a consequence of exercising their right of free movement.

But I fully disagree both with his argumentation and his proposed conclusion which are, in my views, rather disproportionate with the problem to solve.

There are the two ways to solve the problem, the European and the national ones.

As shown by Rainer Bauböck's comments, the national way would lead towards difficult and tricky considerations, like acquisition and loss of nationality by EU citizens. I agree that those topics will probably have to be considered at EU level sooner or later. I also agree with Rainer Bauböck that all immigrants should be offered opportunities to naturalise after they have become long-term residents, at least if they so wish. Nevertheless for the time being and since the conclusions of the Edinburgh European Council of December 1992, such topics are explicitly considered as outside the EU's competences and no legal basis can be found for them in the present Treaties. I have strong doubts that the case law of the European Court could by itself reverse this consensus and the taboo.

The European way suggested by the 'Let me vote' initiative offers a much lighter solution, much more in line with what European citizenship really is.

I leave the interpretation of the somewhat abstract definition given by the Treaty to lawyers. For me, as a European citizen, I understand European citizenship as the right to be considered as a national by any member state other than the one whose nationality I hold, as soon as I am in relation with its authorities, in one way or another. If, as a German, I drive through the Belgian territory by car at a speed exceeding Belgian limitations, I can of course be fined, but under the same conditions as the nationals of Belgium; 
if, as a Dane, I reside in France, I have to have the same rights as French nationals and this from the first day of my stay. Even outside the EU, any member state has to give me consular protection, under the same conditions as those applied to its nationals. And, if I receive the rights to vote in municipal and European elections, it is always under the same conditions as the nationals of the state where I reside.

Being considered as if I were a national in my country of residence, where is the need for asking for the nationality of that country, as long as the EU respects diversity? One of my obligations as an EU citizen is to respect my host country and to participate fairly in its social and political life. But why should I ask for its nationality, if I still feel French, German or Polish?

Of course, there is a well-known limited number of exceptions to this national treatment and some discriminations remain.

The purpose of the 'Let me vote' initiative is to abolish one of them.

It is ambitious in its scope, by covering all 'political' elections, regional, legislative, referenda, presidential, etc. Due to the diversity of elections in member states, it would of course not be possible to enter into a precise enumeration. I understand also that the initiative suggests giving the rights to all EU residents, not only to long-term or permanent ones. This is in line with existing rights to vote in municipal and European elections.

Nevertheless, it can be useful to recall that the number of citizens concerned is rather limited. In official documents from the European Commission, the figure of 12 million people is frequently quoted to measure the total number of EU citizens residing in a member state other than their own.

Granting the right to vote to EU citizens will therefore hardly modify the political landscape in any member state, while it will contribute to the respect of EU citizens' fundamental rights, in particular the right to participate in regular elections in the country where they reside as laid down in Article 3 of the First Protocol to the European Convention on Human Rights. It will also contribute to reducing the so-called 'democratic deficit' by fully guaranteeing their representation in EU legislation through the vote of their host country government in the Council and the position taken by national parliaments in EU procedures according to the rules laid down by the Treaty.

Obviously, this representation is not guaranteed in the situation mentioned by Rainer Bauböck where EU citizens lose their voting rights in national elections in their countries of origin. 
In the same vein as for the European elections, EU citizens should be given the choice to vote either in their host country or in their member state of origin if such a right exists in that last country.

The idea proposed by the 'Let me vote' initiative is not a new one. It has already been discussed in many forums and was even flagged by the European Commission in its 5th Report on European Citizenship in 2004.

It is clear that, in the light of developments sustained in fields like the areas of freedom, justice and security, the representation in EU legislation through the Council, as well as through the European Parliament, has to be fully ensured if the Union is to be a democracy.

Open Access This chapter is licensed under the terms of the Creative Commons Attribution 4.0 International License (http://creativecommons.org/licenses/by/4.0/), which permits use, sharing, adaptation, distribution and reproduction in any medium or format, as long as you give appropriate credit to the original author(s) and the source, provide a link to the Creative Commons license and indicate if changes were made.

The images or other third party material in this chapter are included in the chapter's Creative Commons license, unless indicated otherwise in a credit line to the material. If material is not included in the chapter's Creative Commons license and your intended use is not permitted by statutory regulation or exceeds the permitted use, you will need to obtain permission directly from the copyright holder. 